\title{
Parenting Insight to Shape An Anti-Aggressive Behaviour
}

\author{
Jazariyah, Rina Roudhotul Jannah, and Amin Sabi’ati \\ Received: 20052016 / Accepted: 2505 2016 / Published online: 13122016 \\ ๑) 2016 Association of Indonesian Islamic Kindergarten Teachers Education Study Program
}

\begin{abstract}
Abstrak Penelitian ini dimaksudkan untuk mengungkap pentingnya mengetahui wawasan dan keterampilan dalam pengasuhan anti kekerasan pada anak usia dini sebagai wujud kepedulian terhadap tumbuh kembang anak. Pengasuhan menempati posisi penting dalam pembentukan karakter anak di masa depan. Hal tersebut mendapat perhatian khusus dari pemerintah dunia (WHO), maupun dalam ajaran Islam. Hasil penelitian menunjukkan bahwa meningkatnya kasus agresivitas pada remaja seperti bullying, perkelahian, dan tawuran saat ini merupakan dampak atas perlakuan pengasuhan dengan tingkat kekerasan yang tinggi salah satunya agresivitas ketika masih kanak-kanak. Orang tua maupun lingkungan yang seharusnya menjadi model untuk anak justru masih sering secara kondisional dalam memposisikan diri dalam pengasuhan. Sehingga dalam perkembangannya anak rentan menjadi korban maupun pelaku tindak kekerasan.
\end{abstract}

Kata Kund: Wawasan Pengasuhan, Perilaku Anti Agresif.

\begin{abstract}
A bstract This study aimed to reveal the importance of knowledge parenting's insight and skills of non-violence in early childhood as a manifestation of concern for child development. Parenting occupies an important position in shaping the character of children in the future. It received national attention in the world (WHO), as well as in Islam Religion. The results showed that increasing aggressiveness in juvenile cases such as bullying, fights, and fighting now is the impact on the parenting treatment with a high level of violence aggressiveness when one of them was a child. Children who are at the age of chronic and require the model in each of his behavior often become victims. Thus, in the development of children vulnerable to becoming victims or perpetrators of violence.
\end{abstract}

Keywords Parenting Insight, Anti A ggressive Behavior.

\section{Introduction}

Thereare many cases of concern such as children abused both individual and massive, al ready the daily news of mass media. The event got a lot of thespotlight and the attention both of the parents, government, educators and psychologists since been an increase in aggressive behavior. A ggressive is a violence, in addition to the influence of children socio-culture, parenting that tends to much of the violence also influence the significant for the character building of children to adolescents and adults.

Children in early stage has a high imitation, the child will learn from his life, what they see, hear and feel will have long-term implications. $M$ any parents and people who do not realize how 
to implement parenting with a positive stimulus. Most parents take the conditionally attitude (Irma Hariyani, 2015).

Children who are victims of violence parenting within the scope of family and neighborhood may experience physical disorders, brain damage, mental and emotional, and can cause various problems in both the short and long term. In the short term such as: threats to the safety of the children life, damaging the structure of the family, the emergence of a variety of mental disorders. While in the long term raises the potential of children engaged in violent behavior and abuse in the future, either as perpetrators or victims (M.H Bair-M erritt, $M$ Blackstone, and Feudtner C, 2006: 278-290). So the modeling is good for the care becomes very important for the internal development of the child.

\section{Method}

This type of research used in this research is qualitative research. Qualitative research is a process of investigation to understand the problem based on the creation of a holistic design that formed the words and try to understand and interpret the meaning of a text in a scientific background. Based on the object of study, this research includes the study of literary or library (library research), which is the study of literature through library research. The approach used in this study is the sociological approach as an integral basic between social reality and the Indonesian education, especially early childhood stage.

The data collection technique is the most important step in the study, because the main goal of the study is to get the data, without knowing the data collection, the researchers will not get the standard data that set before. Because this study is a literary or literature study (library research), then the data collection techniques that will be used by reseparentarchers is the documentation (Sugiyono, 2008:308). Document in question is a description of the material, the results of research such as articles, journals, academic thesis, evaluation or works produced by a person or an institution that has no relevance to the research. To supplement the data, the researchers also used some previous research data as secondary data sources, among others, of books, informants, or information etc. Based on this observation the researchers found that the study of the implications of violence in the nurturing of the formation of aggressive behavior is important to do and unique.

\section{The Concepts of Violence in Early Childhood}

Violence according to Black (1951) is the use of force, unjust, and unjustifiable, accompanied by great emotional or uncontrolled anger, sudden, forceful, rude, and insulting. That power, usually physical strength, misused against public rights, the rule of law and public freedoms, so contrary to the law. A ccording to the Law on Elimination of Domestic Violence N 0.23 of 2004, article 1, paragraph (1), violence is an act against a person, especially women and children, misery or suffering physical, psychological and or negligence of household including threat to acts, 
coercion, or deprivation of liberty unlawfully in the household environment. Based on the identification of the cases, violence against children occurs within the domestic sphere (domestic violence), violence in the community (community violence), and violence based on policies or actions of the state (state violence). Community including schools, the environment, and education of children (Nahuda \& dkk, 2007:13).

According to W HO, there are several types of violence against children, namely ( $N$ ahuda et al., 2007:6).

1. Physical violence is an act that causes pain or the potential to cause illness carried by others, can occur once or repeatedly. Physical abuse can be: beaten or slapped, kicked, attracted, pinched, hit with hard objects, dried under the sun.

2. Sexual violence is the involvement of children in sexual activity that does not understand. Sexual violence can also be: mistreatment from others, activities that lead to pornography, sayings porn and harassment sexual organs of a child, sexual immorality and promiscuity in children are done by others with no responsibility, action encouraging or forcing a child to engage in sexual activity which is outrage as the involvement of children in prostitution.

3. Emotional violence is anything that can be hung up a child's emotional development. It can be: words that threaten frighten, to speak harsh, discriminatory treatment, limit social activities and the children creativity.

4. Measures Abandonment and Neglect is the indifference of the parents or the person responsible for the child on their needs, such as: neglect on children's health, the development of emotional neglect (too restrained), malnutrition, abandonment for safety and comfort.

5. Economic violence (commercial exploitation) is the use of child labor to work and other activities for the benefit of parents or others, such as: having the child work excessively.

In Indonesian context, Soeroso also explained that the cause of domestic violence can be classified into two factors, namely external and internal factors. External factors are factors outside of the person. Individuals who do not have aggressive behavior may be able to do the violence when faced the frustrated situations. Prolonged economic hardship or infidelity committed husband or wife are lead to increase to the hard situation. Internal factors concerning the personality of the person in which it is easy to commit acts of violence when facing situations that cause anger and frustration. Personality aggressive typically formed through interaction within the family or the social environment in the past (M.H Soeroso, 2010).

\section{Violence in Parenting, Impacts and Solutions}

Children are like sponges. They absorb quickly what we do and we say (Dorothy Law N olte and Rachel Harris, 2016:3). Children will easily follow the behavior of the people involved in his life. For example, if children are grown with reproach, they learn to curse. Often in the nurturing process we do not focus on the goodness. Shortages or small mistakes made by the children will cover the most of child superiority, so that involuntarily comes reproach or criticism be uttered spontaneously by parents or persons involved in parenting. 
Scolding, cursing, and allusion often expressed spontaneously because the difficulty of controlling emotions. The spontaneous mistake repeatedly will have negative impact to the child. As accomplished learners, children have to absorb what is heard and seen. Ther efore, when the children live with criticism then he learned to curse. This impact is not only felt in the long term but can be felt in the short term. D o not be surprised if they join in the elementary school children currently have a conflict with friends suddenly issued invective, insult and reproach. This incident could be a reflection of the learning outcomes of children at an earlier phase. Kids imitate or practice the same things that he get well at home, in the community or school environment. Children are exposed thousands of images of fights and violence through television and movies. Children may also see and hear about parents who fight with each other. The pattern of aggression in the family can teach children that fighting is a necessity (D orothy Law $\mathrm{N}$ olteand Rachel Harris, 2016:20). A settlement problem in the family performed by the quarrels and fights affect children learns something that they begin to assume that they must fight to survive.

Some child abuses seem to be a common thing, like a pinched, slapped or non verbal violence as insulted. Kids seemed to be the most potential for a parent object as the outlet for their problems. Frequent instances of bad habits that becomea parent, did not have to wait long enough to reap the rewards. At thetime of Parenting Seminar in an early childhood education institutions, a mother complained about his reported attitude is easy to attack another student (hitting, pinching or kicking). At first he thought his aggressiveness because it mimics the behavior of his more adult, then he made an admission that he pinched because of impatience often slap her or threaten her when making a small mistake. These events are always repeated, and after getting parenting materials that explain the nature of the child as the great imitator, She began to realize that the aggressive attitude of her child is taken or learned from her attiudes. She often getting mad to her child because of small mistakes.(Catatan Jazariyah; Saat menjadi Pembicara Parenting Education untuk Wali M urid sebuah RA di Salatiga 15 Desember 2016)

Real portrait of violence on children is now clearly delineated mass media. So when the children in conflict with the law as the perpetrators of violence. Cases like children mistreat their parents, even eliminating the lives of parents, case of pupils that persecute their teacher, or a fight between students seemed to be a real picture portrait of an aggressive stance. KPAI noted that until A pril 2016 there were 298 cases of children in conflict with the law. This figure increased by $15 \%$ from 2015, and of many cases, there were 24 cases in which children as perpetrators of violence physical (Tribun N ews, 2016).

The figures recorded in the data will be continue to increase if no immediate prevention. In order to reduce the case law relating to the aggressiveness of the child, of course with the prevention of violence against children. When children learn from life, then create a peaceful and comfortable life both in the family and society, so that the result obtained is positive.

An overview of the number of cases of children as perpetrators of violence into one of the main impact of the violence perpetrated on children. Children who have experienced violence 
either physical, psychological, sexual or neglected and exploitation has the potential to do the samething in the future. A nother impact as a result of child abuse, among others (U nicef, 2015:7):

1. Child abuse can result death or disability of the body.

2. Child abuse gives rise to an anxious / fearful, shy, low self-esteem, and even can lead to aggressive behavior self-destructive.

3. Violence produce a child with low self-confidence.

4. Anger is difficult to explain, emotionally explosive.

5. Killing others.

6. Imitating violence.

7. Delinquency

Some points to the impact of violence on children are clearly visible one child will do the imitation of behavior that ever happened to him. Children imitate the violence of the same or even worse. It is necessary for prevention as a solution to the increasing acts of violence committed by children as a form of aggressiveness overflow of children. A ggressive behavior derived from the imitation of behavior acquired during rearing both in the family and society.

Some precautions violence against children in the family as follows (U nicef, 2015: 8).

1. Understand child development.

2. Being a good listener.

3. Establish two-way communication with children.

4. Considering children as a friend

5. Provide quality time with children.

6. Do not easy to panic when faced with children who resist.

7. Give praise when children do good.

8. Do not judge young people especially in front of others.

9. Do not give negative nickname in children.

10. Storytelling or tell bedtime.

11. Increase the knowledge of good parenting

12. Following the development of technology and know child converse.

Kids imitate the behavior not only of the family environment, but the scale of further child can mimic the behavior of people both around the house and around the school. For the prevention of any society worth doing. Teachers as parents in the school also has responsibility for the prevention of violence in schools, so that do not let the teacher becoming actors of violonce.

Parents are not the creator of a child, but the guards and protectors. They must protect the child and have deep concern to him as someone who is carrying a very strong belief. It is said that the child is a mandate, which must be maintained and protected. Parents who commit acts of violence against children as has tarnished the trust that has been given.

Parents who have a high temper usually educatetheir children with a high tone as well. N ot infrequently they tweaked or slapped their children or even snapped harshly. Children do not 
have the slightest freedom to do, children are always organized and do things according to the will of her parents. Children do not have the options they prefer. Depressed child living at home with their parents themselves. The children were forced to do their homework even children are also forced to help the family economy, such as selling newspapers, begging, helping his parents sell, etc (Rianawati, 2015).

Such parenting above mentioned categorized as authoritarian upbringing. Parenting is at risk of the emergence of child abuse both physical and psychological. The absence of two-way communication between the peopleand the children cause children to become victims of parental egoism. One of the impacts of this parenting style is a child feeling depressed in the house so that raises the possibility of two attitudes of children; The first, child may become very quiet because accustomed to obey every command of parents. The Second; children tend to do unrest outside the home such as at school. Rebellion is done by aggressive action such as attacking a friend, fighting, making a scene. This behavior carried the child to get people's attention, because at home their desires are often not a concern of their parents.

\section{Prohibition of Child A buse in Islam}

To find out the views of Islamic Education against violence on children. Results from this study is that factors of child abuse there are two; internal and external. Internal factors are derived from the child's personal, such as stress. W hile external factors are factors originating from outside the children's personalities such as from parents, caregivers, communities, authoritarian parenting. Parents who do violence in parenting becomes negative models for their children.

Authoritarian parents tend to use rigid rules in educating children. Violations by the children will be faced by parents with harsh punishments. The impact of violence on children is as follows: children who have lost their right to enjoy childhood, children become victims of irregularities parents, often become victims of exploitation and oppression of adult humans, emotional instability, and behavior patterns that tend to be aggressive easily engage in fights, violence, substance abuse, free sex, and a tendency to antisocial behavior.

Islam condemns all forms of violence, including violence against children as spoken Allah subhanahu wa ta'ala:

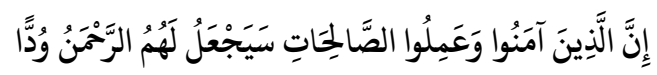

"Those who believe and do deeds of righteousness, will God the Merciful will instill in (hearts) they love."(Q s. M aryam: 96).

In another verse Allah Subhanahu Ta'ala says:

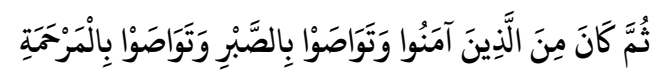

"And he (nor) among those who believe, and enjoin patience and enjoin compassion." (QS. AI Balad: 17)

Islamic religious education materials as a solution to violence in children. To eliminate child abuse must be taken some kind of education, among others, moral and intellectual 
education. Children's education should be free, with the intent that should become a guide and pay attention to the children, so that violence against children can be eliminated. Then spoke the need for affection between parents to their children, it is described in several hadiths of the Prophet shalallahu'alai hi wa sallam, as mentioned below:

Rasulullah shalallahu'alaihi wa sallam said:

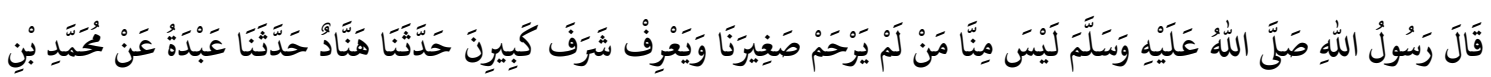

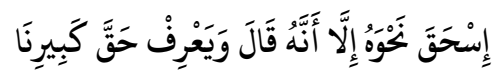

Sunan Tirmidzi 1843: "M essenger of Allah said: "Excluding our comity, people who do not love children nor honor our parents."

Hadith Rasulullah shalallahu'alaihi wa sallam above mentioned people who do not have a sense of love for little children do not belong to his category. So that the love of parents for their children is very important.

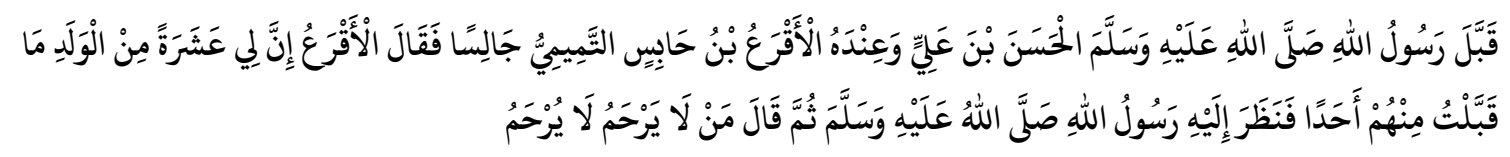

'Prophet sallallaahu 'alaihi wasallam never kissed Al-Hasan bin Ali, while besidehim, Al Aqra' ibn Habis At Tamimi was sitting, then Aqra 'said;' I have ten children, but I never kiss them once, then the Prophet alaihi wasallam looked at him and said: "Whoever does not love then he will not be loved."(Shahih Bukhari 5538).

\section{Implications of Violence in Parenting to the Children's Aggresiveness}

The concept of aggression (E Koeswara, 1988) according to Baron is the behavior of individuals who intended to injure or harm another individual who does not want the arrival of these behaviors. According to Buss, aggression can be verbal or physical form, directly or indirectly, and active and passive. This action may be aimed at other people, the environment and the self caused by deep frustration and disappointment that happen to an individual. Tim Kesehatan Jiwa Indonesia stated that aggressive behavior is one disorder aggressive behavior, especially if done repeatedly and settled, at least lasts for 6 months (Fatwa Tentama, 2012: 162-232):

1. V erbal aggression: involves attempts to hurt others through words and not deeds.

2. Physical aggression: it involves the behavior of visible (overt) that is intended to harm the victim in a certain way.

3. Directly aggression: behavior leads directly to the victim.

4. Indirect aggression: behavior leads through other means or exceed the attacks against people or objects that are valuable to the victims.

5. Active aggression: Hurting victims through the implementation of specific actions.

6. Passive aggression: Hurting victims through specific actions.

Lancelotta and $V$ aughn declare there are four types of aggressive behavior and reactions of children to social acceptance, namely: (1) physical aggression provoked, attacking back following the provocation; (2) exploded aggression, angry for no apparent reason; (3) verbal aggression, for 
example: threatening; and (4) indirectly aggression, that is like telling the teacher that other students who make mistakes (Sharon V aughn \& Candace S Bos, 2012).

A ggressive behavior is reflected in the way a person communicates, according Rigacion in (Suciati, 2015:152) explained that there are several properties owned by someone who has a communication style agresiff.

1. Dominating, did not give a chance to others to give a different opinion.

2. Rigid, demanding others to be obedient to the smallest thing and being outstanding carefully.

3. Stubborn, unwilling to listen to advice from others.

4. Impulsive, irritability without thinking about other people's feelings.

5. Competitive, criticizing the work or the appearance of others to highlight its advantages.

6. A uthoritarian, demanding others to accept his opinion.

7. Not callous behavior care less about other people's feelings.

8. Easy to give a negative assessment of others without giving consideration.

Aggressive behavior is not merely expressed in physical behavior but according to Buss in (Suciati, 2015:160) there are some verbally aggressive behavior that is:

1. The active verbal aggression directly, including verbal acts by individuals or groups a way to deal directly with individuals or other groups, for example: cursing, insulting and cursing.

2. Passive direct verbal aggression, verbal aggression, namely action by theindividual / group of individuals / groups without direct verbal contact. such as refusing to talk or mute.

3. The active verbal aggression indirectly, for example: spreading slander or pitting.

4. The passive verbal aggression indirectly, for example: do not provide support or do not give voting rights.

Bringham stated that there are three factors that A ffect aggressive behavior (1) learning, (2) strengthening (reinforcement) and (3) imitation of the model. Behavior presented by the models, the models Considered or imitated by students (no reinforcement by model), behavior (ability encoded and stored by the learner), the processing codes of the symbolic, the scheme triangular relationship between the environment, personal factors and behavior (A Bandura, 1997).

$M$ organ, in theintroduction of psychology book, learning is any relatively permanent change in behavior that occurs as a result of training or experience. Sears, states that behavior is usually the reactions are studied for their reinforcement. Behavior can be formed for learning through rewards and punishments. Sears also said that the figure most likely to become a model for the child is the parents themselves, the aggressivebehavior of children largely depends on how parents treat them and themselves (Sears D, 1988).

Violence recorded by the child has a long-term impact, both sexual violence, psychological, physical, and neglect. Problems will also show its influence in adulthood, namely the inability to develop coping abilities or mimic effective. Most of these children will become adults who are prone to depression and showed symptoms of traumatic, until finally at high risk of becoming perpetrators of violence or intimate relationships they intertwine as adults (G .E Robinson, 2016). Here are some forms imposible as an implication of violence in child care, including. 
First, get harsh treatment experiences during childhood care has been identified as one of the important factors that could explain the occurrence of violence in intimate relationships in adulthood. Boys who grow up in families where violence risk triples to the perpetrators of violence are aggressive towards his wife and their families in the future, while girls will develop into adult females who tend to be passive and have a high risk of becoming victims of violence in their families later (B.A A rrigo \& S.L Shipley, 2005).

Second, the experience witnessed, heard, experienced violence within the family cause negative effects on the security, stability and welfare of the children live (B.E Carlson, 2000:321340). The experience of violence can generate direct victims (direct violence) and indirect victims (who witnessed violence). Several previous studies have found that the direct victims of violence (abuse and neglect) and indirect victims of violence have the same vulnerability traumatized and imitation, and eventually also have the possibility to engage in intimate relationships are filled with violent and aggressive behavior in adulthood (A.E Appel \& G.W Holden, 1988:578-599).

Third, a longitudinal study by Emery explained that the relationship between trauma to violence will lead to psychological problems weaken with increasing age of the child at the time of experiencing violence for the first time. Or in other words the possibility of the emergence of behavioral problems due to violence in parenting experience will be lower if the child is experiencing at an older age. This indicates that the aged and more mature understanding can be a protective factor on the negative effects of trauma and impersonation (C.R Emery, 2011: 15411558).

Fourth, other explanations submitted by McGee, who discovered that individuals who witnessed or experienced violence in her childhood self-esteem (self-esteem) is lower than individuals who did not experience violence. Negative influence of violent trauma and treated with an aggressive stance on self-esteem were found to occur in women and men, but more prominently seen in women (A H oltzworth-M unroe, N Smutzler, and E Sandin, 1997: 179-213).

$M c G e e$ explains that self-esteem of girls who watched violent and aggressive victims tend to weaken as a result of living with feelings of shame and some pressure on cruel and dismissive attitude of the perpetrators of violence (most of whom are male) at his home. Therefore, the prices in the research of domestic violence are often seen as a factor supporting the resilience of children who are victims. High self-esteem of children who are found also support attachment between children and parents after the incidents of violence and subsequent social support from attach figure will affect the child's ability to manage trauma and imitation (A .A Levendosky, A.C H uthBocks, and M .A Semel, 2002:206-2017).

A study shows that children who are aggressive high (from birth to 2 years of age) had a lot of pressure early in life. Their mother feel more stress than mothers whose children are not aggressive high. M others facemore social stressors such as being a single mother or less education and income (JaneBrooks, 2011:432). Thisstudy describes theimplications for the care of the child agresive attitude. Even the parents had to be wary of care since I was in the womb. 
Some children are physically aggressive, hitting and injuring others. Some children being verbally abusive-deprecating, mocking and humiliating others. Such types of aggression that is open, can be seen and be characterized by boys than girls. A nother form of aggression, right with "aggression relationship" is more subtle, not easily detected and characterized by girls. Consist of measures designed to separate the child from friends defamatory or untrue rumor about children being targeted. Set the other children to avoid 'the target'. Aggressive behavior intended to hurt others and harm to others (Jane Brooks, 2011: 512-513).

A ggressive posture caused children imitate thebehavior of parents is in friendship at school or in the neighborhood, can lead to another problem that is bullying. Bullying occurs when aggressive child makes a child or a small group of children as a target outlet for aggressiveness. This behavior can be done both physically and unpleasant words. Positive parenting strategies that reduce aggression in children of men and women. When a parent gives positive attention, respect the child's behavior was good, and avoid criticism and harsh penalties, the aggressive nature of children will decrease. Positive parenting will be effective even if the family is experiencing stress and problems.

\section{Conclusion}

Based on the above presentation of non-violence is emphasized that nurturing is crucial in the formation of the child's behavior and minimize the bad developments on the psychological and mental of child. It is sought by the government to legitimize the anti-violence laws, child protection rights and other juridical regulations that have the force of law for noncompliance. Reference on child care has also been described in detail in the teachings of I slam are the Q ur'an and the hadith's teachings to treat children with the best.

Forms of violence in nurturing has many varieties one of which is aggressive behavior. The several studies described above can be explained that aggressive behavior can be imitated by children through treatment in the nurturing when childhood by parents, teachers and the surrounding environment. $M$ any impacts of the actions will be visualized on the aggressiveness of the child while growing up. Of some case by case is expected to be a mirror and broaden the parties concerned to break the chain of violence in early childhood nurturing, so that children will no longer be victims or perpetrators later.

\section{Bibliografi}

Appel, A.E, and G.W Holden. "The Co-Occurrence of Spouseand Physical Child A buse: A Review and Appraisal." Journal of Family Psychology 12 (1998): 578-99.

A rrigo, B.A , and S.L Shipley. Introduction to Forensic Psychology Issues and Controversies in Crime and Justice. New Y ork: Elsevier, 2005. 
Bair-M erritt, M.H, M Blackstone, and Feudtner C. "A Systematic Review Physical Health Outcomes of Childhood Exposure to Intimate Partner Violence.” Pediatrics 117 (2006): 278-90.

Bandura, A. Social Learning Theory. N ew Jersey: Englewood Cliffs, PrenticeH all-Inc, 1997.

Brigham, J.C. Social Psychology. N ew Y ork: Harper Collins Publishers, 1991.

Brooks, Jane. The Process of Parenting. Kedelapan. Yogyakarta: Pustaka pelajar, 2011.

Carlson, B.E. "Children Expos Ed to Intimate Partner Violence: Research Findings and Implications for Intervention.” Trauma, Violence and A buse 1 (2000): 321-40.

Emery, C.R. "Controlling for Selection Effects in the Relationship between Child Behavior Problems and Exposure to Intimate Partner Violence." Journal Interpersonal Violence 26 (2011): 1541-58.

Hariyani, Irma, and dkk. "Hubungan Pola Asuh Orang Tua Dengan Perilaku Agresivitas Anak TK Kemala Bhayangkari 13," n.d. http://download.portalgaruda.org/article.php? article $=111874 \&$ val $=2338$.

Holtzworth-Munroe, A, N Smutzler, and E Sandin. "A Brief Review of the Literature on H usband Violence." Aggression and Violent Behavior 2 (1997): 179-213.

Koeswara, E. Agresi M anusia. Bandung: PT Erasco, 1988.

"KPAI Angka Kekerasan Terhadap Anak Meningkat," June 5, 2016. http://www.tribunnews.com/nasional/.

Law Nolte, Dorothy, and Rachel Harris. Anak-Anak Belajar Dari Kehidupannya Nilai Nilai Parenting Klasik Dunia. Yogyakarta: Pustaka pelajar, 2016.

Levendosky, A.A, A.C Huth-Bocks, and M.A Semel. "Adolescent Peer Relationships and Mental Health Functioning in Families with Domestic Violence." Journal of Clinical Child Psychology 31 (2002): 206-18.

M ontessori, M aria. Rahasia M asa Kanak-Kanak. Yogyakarta: Pustaka pelajar, 2016.

Nahuda, and dkk. Pencegahan Kekerasan Terhadap Anak Di Lingkungan Pendidikan. Jakarta: Pusat Pelayanan Terpadu Pemberdayaan Perempuan dan Anak (P2TP2A) Provinsi DKI Jakarta, 2007.

Rianawati. "Perlindungan Hukum Terhadap Kekerasan Pada Anak." Raheema: Jurnal Studi Gender Dan Anak, 2015.

Robinson, G.E. "Current Concepts in Domestic Violence Gail Erlick," Desember 2016. http://www.primarypsy chiatry.com/aspx/article_pf.aspx?articleid=1164.

Sears D, L Peplan, J.L Freeman, Taylor, and Shelley E. Social Psychology. N ew Jersey: Englewood Cliffs, Prentice Hall Inc, 1988.

Soeroso, M .H . Kekerasan Dalam Rumah Tangga Dalam Perspektif Yuridis-Viktimologis. Jakarta: Sinar Grafika, 2010.

Suciati. Komunikasi Interpersonal Sebuah Tinjauan Psikologis Dan Perspektif I slam. Yogyakarta: Buku Litera, 2015. 
Sugiyono. M etodePenelitian Pendidikan: Pendekatan Kuantitatif, Kualitatif, Dan R\&D. Bandung: Alfabeta, 2008.

Tentama, Fatwa. “Perilaku Anak Agresif: Asesmen Dan Intervensinya.” Jurnal KES M AS 6, no. 2 (June 2012): 162-232.

Unicef. M odul Pelatihan Dasar Holistik Integratif, 2015.

Usman, Husaini, and Purnomo SA kbar. M etodologi Penelitian Sosial. Jakarta: Bumi A ksara, 2001. V aughn, Sharon, and Candace S Bos. Strategies for Teaching Students with Learning and Behavior Problem Eight Edition. Boston: Pearson, 2012. 